\title{
Improved Diabetic Control and Hypocholesterolaemic Effect Induced by Long-Term Dietary Supplementation with Guar Gum in Type 2 (Insulin-Independent) Diabetes
}

\author{
A. Aro, M. Uusitupa, E. Voutilainen, K. Hersio, T. Korhonen and O. Siitonen \\ Departments of Medicine and Clinical Chemistry, University of Kuopio, Kuopio, Finland
}

Summary. The effects of dietary supplementation with granulated guar gum $(21 \mathrm{~g} /$ day in three divided doses at the main meals), were compared with placebo response during three months in a doubleblind, cross-over trial in 11 Type 2 (insulin-independent) diabetics. The nine patients who completed the study (two dropped out because of side-effects) showed a significant reduction in both basal and postprandial hyperglycaemia as well as of urinary excretion of glucose during guar gum supplementation. No change in mean bodyweight was observed during the study. Mean fasting and post-prandial plasma insulin levels were similar during both study periods, but the two subjects who received no oral hypoglycaemic agents had lower insulin levels during the guar gum period. Mean serum total- and LDL-cholesterol concentrations were significantly lower during the guar gum period, whereas the HDL-cholesterol level remained unchanged. Long-term administration of guar gum induced a sustained improvement in diabetic control in Type 2 diabetes.

Key words: Type 2 (insulin-independent) diabetes, diabetic control, dietary fibre, guar, serum cholesterol, serum lipoproteins, calciuria

Dietary fibre has marked effects on blood glucose concentration in both normal subjects and diabetics. Post-prandial hyperglycaemia is reduced when meals are enriched with guar gum $[1,2]$, by consumption of high-carbohydrate, high-fibre diets $[3,4]$, or with diets rich in dietary fibre $[5,6]$. Cereal fibre has been less effective [7].

The reduction of post-prandial hyperglycaemia, induced by gel-forming fibre, seems mainly to depend on delayed gastric emptying [8] and not on impaired absorption of carbohydrates [7]. In longterm studies a sustained improvement in the control of diabetes for periods of weeks or months has been observed $[3,9,10]$, and a prolonged effect of a single dose of guar gum has been demonstrated [11]. These findings suggest that factors other than the effect on gastric emptying may be involved.

In order to elucidate the long-term effects of gelforming fibre in diabetes, we have performed a controlled study on the effects of a 3 month dietary supplementation with guar gum on glucose and lipid metabolism in a group of subjects with type 2 (insulin-independent) diabetes.

\section{Materials and Methods}

\section{Subjects}

Eleven insulin-independent diabetics were studied. Two of these dropped out because of side-effects. The nine subjects who completed the study (five males and four females) had a mean age of 53 years (range 39-69 years) and a mean duration of diabetes of 6.5 years (range $1-15$ years). The mean relative bodyweight was $116 \%$ of ideal weight (Metropolitan Life Insurance Tables), and only two subjects were more than $20 \%$ overweight. Of the subjects, two were treated with diet only, while seven were on treatment with the sulphonylurea derivative glibenclamide, $10-15 \mathrm{mg} /$ day. The drug therapy was kept constant throughout the study. Informed consent was obtained from each subject prior to the beginning of the study. Approval for the study had been given by the Ethical Committee of the University of Kuopio.

\section{Experimental Design}

A double-blind, cross-over trial designed to include two successive 3 month periods during which the diet was supplemented either with $21 \mathrm{~g}$ of guar gum or placebo.

A granulated, slow-gelling guar gum preparation was used (Guarem ${ }^{(3)}$ Remeda Pharmaceuticals, Kuopio, Finland). The 
Table 1. Blood and urinary glucose values in nine Type 2 (insulinindependent) diabetics during daily dietary supplementation with $21 \mathrm{~g}$ guar gum or placebo

\begin{tabular}{lllll}
\hline & \multicolumn{3}{l}{ Dietary supplementation } \\
\cline { 2 - 5 } & $\begin{array}{l}\text { Duration } \\
\text { (months) }\end{array}$ & & \\
\hline & 1 & $11.5 \pm 1.1$ & $10.6 \pm 1.0$ \\
\hline $\begin{array}{l}\text { Fasting blood glucose } \\
\text { (mmol/l) }\end{array}$ & 2 & $12.7 \pm 1.2$ & $10.7 \pm 1.2^{\mathrm{a}}$ \\
& 3 & $12.1 \pm 1.3$ & $10.0 \pm 0.8^{\mathrm{a}}$ \\
& 1 & $30.3 \pm 10.2$ & $24.2 \pm 9.8$ \\
Urinary glucose & 2 & $42.7 \pm 15.3$ & $24.9 \pm 13.4$ \\
(g/24 h) & 3 & $48.6 \pm 11.3$ & $19.4 \pm 6.0^{\mathrm{a}}$ \\
\hline
\end{tabular}

Results are given as mean \pm SEM

${ }^{a} p<0.02$ (paired $\mathbf{t}$-test)

granules are prepared using ethyl cellulose and gelatin spirit, dried at $+50^{\circ} \mathrm{C}$. Their diameter is less than $2.5 \mathrm{~mm}$. The placebo preparation consisted of similarly prepared wheat flour $(0.3 \mathrm{MJ}=$ $75 \mathrm{kcal}$, and $0.7 \mathrm{~g}$ of dietary fibre $/ 21 \mathrm{~g}$ ).

The subjects were given one sachet of $7 \mathrm{~g}$ of the granules with the three main meals. This was mixed with $2 \mathrm{dl}$ of fluid, and ingested within 1-2 min at the beginning of meals. No diet records were obtained, but subjects were advised not to change their dietary habits during the study. Their previous dietary instructions recommended $50 \%$ of energy from carbohydrates, $20 \%$ from proteins, and $30 \%$ from fats. The order of the preparations was determined randomly: five of the subjects started with guar gum and four with placebo.

Bodyweight, blood glucose concentration and 24-h urinary glucose excretion were determined at the beginning of the study and after one, two and three months of each test period. Serum lipids and serum and urinary calcium were estimated at the beginning and after three months of each period. The side-effects were registered monthly.

On the last day of each three-month period the subjects were admitted to hospital for one test-day during which they were given a standard diet of $5.9 \mathrm{MJ}(1,400 \mathrm{kcal})$, supplying $55 \%$ of the energy as carbohydrates, $15 \%$ as proteins, and $30 \%$ as fats. The breakfast and the evening snack yielded $1.2 \mathrm{MJ}(280 \mathrm{kcal})$ and the lunch and the dinner $1.8 \mathrm{MJ}(420 \mathrm{kcal})$ each. The guar gum and the placebo granules were administered at the beginning of breakfast, lunch and dinner. The lunch was composed of $40 \mathrm{~g}$ chicken, $120 \mathrm{~g}$ potatoes, $40 \mathrm{~g}$ wholemeal rye-bread, $11 \mathrm{~g}$ butter, $80 \mathrm{~g}$ carrots, $30 \mathrm{~g}$ lettuce, $10 \mathrm{~g}$ paprika, $10 \mathrm{~g}$ cucumber and a pudding made of $20 \mathrm{~g}$ cowberries and $7 \mathrm{~g}$ hulled wheat. The meal was ingested within $20 \mathrm{~min}$. Blood samples were obtained for determination of blood glucose and plasma insulin before breakfast (after a 12-h fast), before lunch and 15, 30, 45, 60,90, and $120 \mathrm{~min}$ after lunch ended, and before and $1 \mathrm{~h}$ after the end of the evening snack. The subjects took their usual drugs including the sulphonylureas.

\section{Assays}

Glucose was assayed by the glucose oxidase method Glox (Kabi $\mathrm{Ab}$, Sweden) and insulin by radioimmunoassay RIA-Gnost (Behringwerke, West Germany). Serum lipoproteins were separated by uitracentrifugation at $\mathrm{d} 1.006$, followed by precipitation of the bottom fraction by dextran sulphate and $\mathrm{MgCl}_{2}$ [12]. Enzymatic methods were used for the determination of cholesterol [13] and triglycerides [14]. Calcium from the serum was assayed by
Auto-Analyzer and from the urine by atomic absorption spectrometry. The results of the test periods were compared by the Student's t-test for paired samples. The results are given as the mean $\pm S E M$.

\section{Results \\ Bodyweight}

The mean bodyweight of the nine subjects who completed the study was $70.7 \mathrm{~kg}$ after the guar gum period and $70.2 \mathrm{~kg}$ after the placebo period. The largest individual fluctuations were an increase of 1.7 and a decrease of $3 \mathrm{~kg}$ during guar gum and an increase of 2.8 and a decrease of $3 \mathrm{~kg}$ during the control period.

\section{Blood and Urinary Glucose}

At the beginning of the study, the fasting blood glucose concentration was $10.6 \pm 0.9 \mathrm{mmol} / 1$ (range 6.8-14.4 mmol/1) and the 24-h excretion of glucose $30.3 \pm 17.5 \mathrm{~g}$ (range $0-166 \mathrm{~g}$ ).

The fasting blood glucose level was lower during guar gum supplementation throughout the threemonth period and, concomitantly, the mean glucose excretion was markedly reduced (Table 1 ). The mean blood glucose level of the subjects who started on guar gum was $9.4 \mathrm{mmol} / 1$ before the study, $9.4 \mathrm{mmol} / 1$ after guar gum, and $11.1 \mathrm{mmol} / 1$ after placebo. In those who started on placebo, it was $11.5 \mathrm{mmol} / \mathrm{l}$ before the study, $13.5 \mathrm{mmol} / \mathrm{l}$ after placebo, and $10.7 \mathrm{mmol} / \mathrm{l}$ after guar gum. The smaller glucose excretion after one month on placebo (Table 1) is due to a carry-over effect in the group which started on guar gum showing a mean glucose excretion of $19 \mathrm{~g}$ after one month, and of $40 \mathrm{~g}$ after three months on placebo.

During the test-day at hospital, both the fasting and the post-prandial blood glucose levels were significantly lower during guar gum as compared with the control period (Fig. 1). The post-prandial increment of blood glucose was slightly less when guar gum was consumed but the difference to the control period was not statistically significant. During guar gum supplementation, the blood glucose levels were significantly lower before the evening snack $(10.2 \pm$ $1.0 \mathrm{mmol} / 1$ during guar gum, $12.5 \pm 1.3 \mathrm{mmol} / 1$ during placebo, $p<0.05)$ and $1 \mathrm{~h}$ after it $(10.3 \pm 0.9$ and $12.9 \pm 1.1 \mathrm{mmol} / \mathrm{l}$, respectively, $p<0.01)$.

\section{Plasma Insulin}

Plasma insulin concentration after a 12 -h fast at the end of the three-month period was $10.9 \pm 3.0 \mathrm{mU} / 1$ in patients on guar gum and $11.0 \pm 2.6 \mathrm{mU} / 1$ in the 

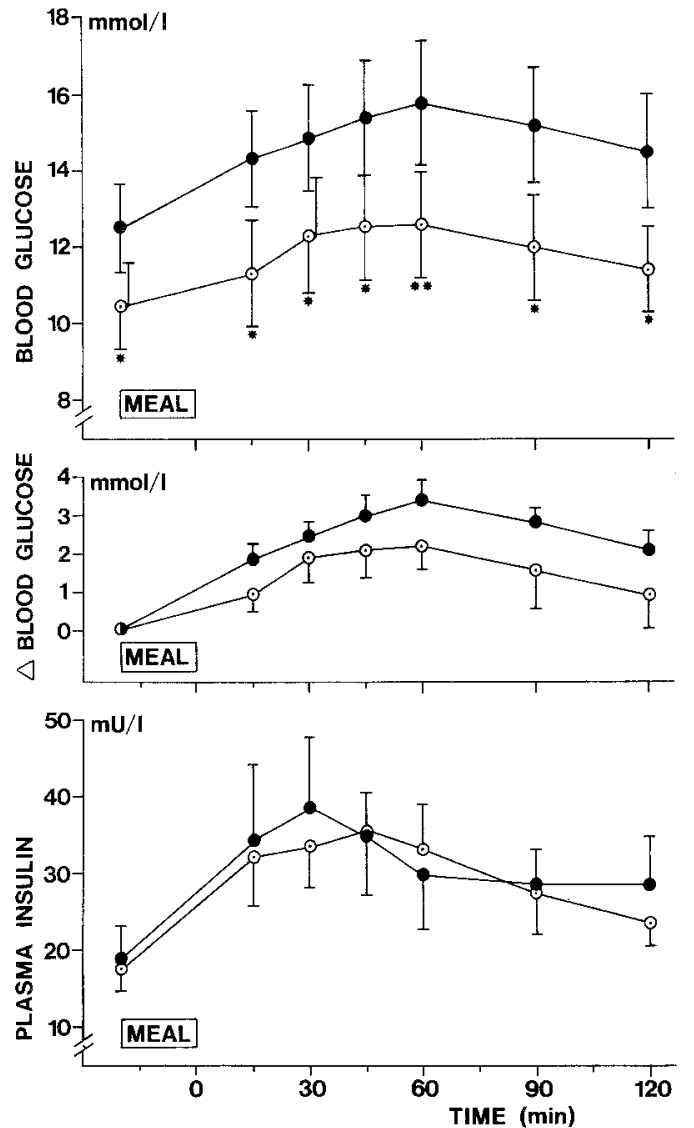

Fig. 1. Blood glucose and plasma insulin levels before and after a standard lunch in nine Type 2 (insulin-independent) diabetics during dietary supplementation with guar gum $(\odot-\odot)$ or placebo $(\bullet-\bullet)$

$* p<0.05 ; * * p<0.01$ (paired t-test). Values are mean \pm SEM

Table 2. Serum and lipoprotein cholesterol and triglyceride concentrations in eight Type 2 (insulin-independent) diabetics after three months of daily dietary supplementation with $21 \mathrm{~g}$ guar gum or placebo

\begin{tabular}{lll}
\hline & \multicolumn{2}{l}{ Dietary supplementation } \\
\cline { 2 - 3 } & Placebo & Guar gum \\
\hline Cholesterol (mmol/1) & & \\
$\quad$ Whole serum & $7.33 \pm 0.39$ & $6.28 \pm 0.48^{\mathrm{a}}$ \\
VLDL & $0.98 \pm 0.15$ & $0.82 \pm 0.14$ \\
LDL & $5.16 \pm 0.34$ & $4.30 \pm 0.40^{\mathrm{a}}$ \\
HDL & $1.19 \pm 0.10$ & $1.17 \pm 0.14$ \\
& & \\
Triglycerides (mmol/1) & & \\
Whole serum & $1.63 \pm 0.24$ & $1.81 \pm 0.37$ \\
VLDL & $1.13 \pm 0.21$ & $1.36 \pm 0.32$ \\
LDL & $0.39 \pm 0.09$ & $0.33 \pm 0.05$ \\
HDL & $0.11 \pm 0.02$ & $0.11 \pm 0.02$ \\
\hline
\end{tabular}

Results are given as mean \pm SEM

" $p<0.02$ (paired t-test) placebo group. Pre- and post-prandial plasma insulin levels were the same in both groups (Fig. 1). However, the two subjects who were on dietary therapy only, showed a clear reduction in plasma insulin levels during the guar gum period. During the placebo period, peak post-prandial plasma insulin levels were 91.5 and $90.0 \mathrm{mU} / 1$ at 30 and $15 \mathrm{~min}$ after the meal. During the guar gum period, the peak concentrations were 48.7 and $40.7 \mathrm{mU} / 1$ and occurred later, at 60 and $45 \mathrm{~min}$ after the meal.

\section{Serum and Lipoprotein Lipids}

Before the study, the mean fasting serum cholesterol concentration was $6.73 \pm 0.58 \mathrm{mmol} / 1$ (range $5.30-8.98 \mathrm{mmol} / \mathrm{l})$. Three of the subjects had a serum cholesterol level exceeding $8 \mathrm{mmol} / \mathrm{l}$. The mean triglyceride concentration was $1.62 \pm$ $0.51 \mathrm{mmol} / 1$ (range $0.78-4.60 \mathrm{mmol} / 1$ ). Two of the subjects had a triglyceride level that exceeded $2 \mathrm{mmol} / \mathrm{l}$. The patient with the highest serum triglyceride level had to be excluded because of incomplete samples.

The mean serum cholesterol concentration was significantly lower during the guar gum period. This was due to a significantly lower LDL-cholesterol level (Table 2). There was no difference in serum HDL-cholesterol concentration, but the LDL/HDLcholesterol ratio was lower in the guar gum period $(4.09 \pm 0.65)$ than in the placebo period $(4.64 \pm$ 0.59 ). This difference was not statistically significant. There was no difference in the triglyceride concentrations of whole serum and in lipoprotein fractions (Table 2).

\section{Serum and Urinary Calcium}

The serum calcium concentration was the same during supplementation with guar gum $(2.42 \pm$ $0.03 \mathrm{mmol} / \mathrm{l})$ and with placebo $(2.38 \pm 0.03 \mathrm{mmol} / \mathrm{l})$, but excretion of urinary calcium was significantly lower $(2.64 \pm 0.67 \mathrm{mmol} / 24 \mathrm{~h})$ during the guar gum period when compared with the placebo period $(3.80 \pm 0.74 \mathrm{mmol} / 24 \mathrm{~h}, p<0.025)$.

\section{Side-Effects}

Two of the 11 subjects who started the study stopped guar gum treatment because of meteorism and abdominal discomfort. Other side-effects were mild but flatulence was universally reported with guar gum. 


\section{Discussion}

In this study, dietary supplementation with guar gum induced a significant and sustained reduction in basal hyperglycaemia, with only a slight reduction in the post-prandial increment of blood glucose. The effect is similar to that found during a high-carbohydrate diet containing natural fibre [4] and differs from the findings of studies on the post-prandial effects of guar-containing test meals $[1,2]$. Most subjects in the present study were hyperglycaemic despite treatment with oral agents. The change in mean blood glucose concentration was rather small during the guar gum period, whereas the diabetic control clearly deteriorated during the placebo period. One possible explanation for this finding could be seasonal variation in the composition of the diet. This study was started during late summer and autumn, when domestic vegetables and legumes are easily available in Finland, and it was completed in the winter in different conditions.

In studies on high-carbohydrate, high-fibre diets $[3,4]$, the proportion of carbohydrates has been altered in addition to the content of dietary fibre. In the present study, only the amount of guar gum in the diet was changed. The results are very similar to those of a recent study in which large amounts of fibre from natural sources were used under metabolic ward conditions [6]. The results are not explained by changes in the bodyweight of the subjects. As it was possible to maintain a lower blood glucose level despite similar plasma insulin levels, sensitivity to insulin was increased. This was most marked in the two subjects who had relatively mild diabetes and who received no oral hypoglycaemic agents. In addition to reduced plasma insulin levels, reduced plasma glucagon and GIP concentrations have been found during dietary supplementation with fibre $[5,15]$. The long-term effects may be different from the acute effect on gastrointestinal motility and postprandial blood glucose response, but the smaller post-prandial excursions of blood glucose may also result in metabolic changes leading to improved glucose control [11]. Dietary factors, including fibre, may also modify the binding of insulin to receptors [16].

The preparations were consumed as one bolus at the beginning of the main meals. The importance of proper timing and mixing of the guar gum supplements have been stressed [17]. Our results suggest it is not necessary to premix the fibre with every carbohydrate portion in order to improve long-term diabetic control. Furthermore, providing guar is taken with the main meals, it is not necessary to administer it with snacks to achieve the favourable effects on blood glucose and serum LDL-cholesterol levels.

The poor palatability of guar gum preparations has presented many difficulties [18]. The only acceptable way of administering guar gum in long-term practice has been in the form of guar crispbread [9, $10,19]$ which, however, limits the possibilities of utilizing dietary carbohydrates from other sources and thus alters the normal diet of the diabetics. A more acceptable way of dietary supplementation with guar gum is addition as slow-gelling preparation.

Side-effects from guar gum were mostly mild, but two subjects could not finish the study, suggesting that this therapy would not suit all diabetics.

The reduction in serum total and LDL-cholesterol concentration, probably caused by increased excretion of cholesterol in bile acids [20], has been described in hypercholesterolaemic subjects [19]. Reduction in the LDL/HDL-cholesterol ratio probably reduces the risk of coronary heart disease [21].

The reduced urinary excretion of calcium is partly explained by the reduced glucose excretion [22], but it is possible that some of this is due to impaired calcium absorption from the gut.

We conclude that dietary supplementation with guar gum improves diabetic control in Type 2 diabetes. It also decreases serum LDL-cholesterol concentration without affecting the level of HDL-cholesterol, thus inducing a favourable change in the serum lipoprotein pattern. The results give indirect support to the theories which link the incidence of diabetes to the fibre content of the diet [23] and emphasize the role of abundant fibre intake in the treatment, and possibly also in the prevention, of Type 2 diabetes. Due to the combined favourable effects on glucose and lipid metabolism, dietary enrichment with guar gum appears to be a useful adjunct to the therapy of Type 2 diabetes, especially in the presence of coexistent hypercholesterolaemia.

Acknowledgements. This work was supported by the Nutrition Research Foundation of Finnish Sugar Co. Ltd. A. A is in receipt of a research grant from the State Medical Research Council of Finland. We would like to thank Mrs. Terttu Kumpulainen and personnel working on the Research Ward for technical assistance.

\section{References}

1. Jenkins DJA, Goff KV, Leeds AR, Alberti KGMM, Wolever TMS, Gassull MA, Hockaday TDR (1976) Unabsorbable carbohydrates and diabetes: decreased post-prandial hyperglycaemia. Lancet 2: 172-174

2. Jenkins DJA, Leeds AR, Gassull MA, Cochet B, Alberti KGMM (1977) Decrease in post-prandial insulin and glucose concentrations by guar and pectin. Ann Intern Med 86: 20-23

3. Anderson JW, Ward K (1978) Long-term effects of high-carbohydrate, high-fiber diets on glucose and lipid metabolism: a 
preliminary report on patients with diabetes. Diabetes Care 1: $77-82$

4. Simpson RW, Mann JI, Eaton J, Moore RA, Carter R, Hockaday TDR (1979) Improved glucose control in maturity-onset diabetes treated with high-carbohydrate-modified fat diet. $\mathrm{Br}$ Med J 1: 1753-1756

5. Miranda PM, Horvitz DL (1978) High-fiber diets in the treatment of diabetes mellitus. Ann Intern Med 88: $482-486$

6. Rivellese A, Riccardi G, Giacco A, Pacioni D, Genovese S, Mattioli PL, Mancini M (1980) Effect of dietary fibre on glucose control and serum lipoproteins in diabetic patients. Lancet 2: $447-450$

7. Jenkins DJA, Wolever TMS, Leeds AR, Gassull MA, Haisman P, Dilawari J, Goff DV, Metz GL, Alberti KGMM (1978) Dietary fibres, fibre analogues, and glucose tolerance: importance of viscosity. Br Med J 1: 1392-1394

8. Holt S, Heading RC, Carter DC, Prescott LF, Tothill P (1979) Effect of gel fibre on gastric emptying and absorption of glucose and paracetamol. Lancet 1: 636-639

9. Jenkins DJA, Wolever TMS, Nineham R, Taylor R, Metz GL, Bacon S, Hockaday TDR (1978) Guar crispbread in the diabetic diet. Br Med J 2: 1744 -1746

10. Jenkins DJA, Wolever TMS, Nineham R, Bacon S, Smith R, Hockaday TDR (1979) Dietary fiber and diabetic therapy: a progressive effect with time. In: Camerini-Davalos DA (ed) Treatment of early diabetes. Plenum Press, New York, pp 275-279

11. Jenkins DJA, Wolever TMS, Nineham R, Sarson DL, Bloom SR, Ahern J, Alberti KGMM, Hockaday TDR (1980) Improved glucose tolerance four hours after taking guar with glucose. Diabetologia 19: 21-24

12. Penttilä IM, Voutilainen E, Laitinen P, Juutilainen P (1981) Comparison of different analytical and precipitation methods for the direct estimation of serum high-density lipoprotein cholesterol. Scand J Clin Lab Invest (in press)

13. Röschlau P, Bernt E, Gruber W (1974) Enzymatische Bestimmung des Gesamt-Cholesterins im Serum. Z Klin Chem Klin Biochem 12: 403-407

14. Wahlefeld AW (1974) Triglycexides. Determination after enzymatic hydrolysis. In: Bergmeyer HU (ed) Methods in enzymatic analysis. Academic Press, New York, pp 1831-1835

15. Morgan LM, Goulder TJ, Tsiolakis D, Marks V, Alberti KGMM (1979) The effect of unabsorbable carbohydrates on gut hormones. Modification of post-prandial GIP secretion by guar. Diabetologia 17: 85-89

16. Pedersen O, Hjøllund E, Lindskov HO, Schwartz Sørensen N (1980) Increased insulin receptors on monocytes from insulindependent diabetics after a high-starch, high-fibre diet. Diabetologia 19: 306

17. Jenkins DJA, Nineham R, Craddock C, Craig-McFeely $P$, Donaldson K. Leigh T, Snook J (1979) Fibre and diabetes. Lancet 1: 434-435

18. Williams DRR, James WPT, Evans IE (1980) Dietary fibre supplementation of a 'normal' breakfast administered to diabetics. Diabetologia 18: 379-383

19. Jenkins DJA, Reynolds D, Slavin B, Leeds AR, Jenkins AL, Jepson EM (1980) Dietary fiber and blood lipids: treatment of hypercholesterolaemia with guar crispbread. Am J Clin Nutr 33: $575-581$

20. Miettinen TA, Tarpila S (1977) Effect of pectin on serum cholesterol, fecal bile acids and biliary lipids in normolipidemic and hyperlipidemic individuals. Clin Chim Acta 79: 471-477

21. Kannel WB, Castelli WP (1979) Is the serum total cholesterol an anachronism? Lancet 2: 950-951

22. McNair P, Madsbad S, Christensen MS, Christiansen C, Faber OK, Binder C, Transbøl I (1979) Bone mineral loss in insulintreated diabetes mellitus: studies on pathogenesis. Acta Endocrinol 90: 463-472

23. Trowell HC (1975) Dietary-fiber hypothesis of the etiology of diabetes mellitus. Diabetes 24: 762-765

Received: 21 November 1980

and in revised form: 29 January 1981

Dr. Antti Aro

Department of Medicine

University of Kuopio

SF-70210 Kuopio 21, Finland 